This is the author's final version of the work, as accepted for publication following peer review but without the publisher's layout or pagination.

The definitive version is available at

https://doi.org/10.1080/14615517.2019.1595941

\title{
Investigating the Effectiveness of Strategic Environmental Assessment in Thailand
}

Chaunjit Chanchitpricha* - School of Environmental Health, Institute of Public Health, Suranaree University of Technology, Nakhon Ratchasima, 30000 Thailand; Email chaunjit@g.sut.ac.th

Angus Morrison-Saunders - Edith Cowan University, Australia; North-West University, South Africa; Email A.Morrison-Saunders@murdoch.edu.au

Alan Bond - University of East Anglia, United Kingdom; North-West University, South Africa, Email alan.bond@uea.ac.uk

*corresponding author 


\section{Investigating the Effectiveness of Strategic Environmental Assessment in Thailand}

Chaunjit Chanchitpricha*,a ${ }^{*}$ Angus Morrison-Saunders ${ }^{\mathrm{b}, \mathrm{c}}$, and Alan Bond ${ }^{\mathrm{c}, \mathrm{d}}$

a School of Environmental Health, Institute of Public Health, Suranaree University of Technology, Nakhon Ratchasima, 30000 Thailand

${ }^{b}$ Centre for Ecosystem Management, School of Science, Edith Cowan University, 270 Joondalup Dr, Joondalup, WA 6027, Australia

${ }^{c}$ Research Unit for Environmental Sciences and Management, North-West University, Potchefstroom Campus, Private Bag X6001, Potchefstroom 2520, South Africa

${ }^{d}$ School of Environmental Sciences, University of East Anglia, Norwich Research Park, Norfolk NR4 7TJ, United Kingdom

* Corresponding author: chaunjit@g.sut.ac.th 


\section{Investigating the effectiveness of Strategic Environmental Assessment in Thailand}

Strategic environmental assessment (SEA) was introduced in Thailand in 2005, aiming to direct decision making at the strategic level (policy, programme, plan) towards sustainable development (SD). Given reforms to the SEA requirements in 2018 , it is timely to evaluate emerging SEA experience in the Thai context to inform future practice. The effectiveness of 14 SEAs was investigated based on a version of a recently published framework which substitutes 'legitimacy' for normative effectiveness and pluralism, modified through the addition of disaggregated subcriteria associated with each dimension of effectiveness (procedural, substantive, transactive and legitimacy), to facilitate a richer understanding of the effectiveness of practice. This more detailed effectiveness framework enabled a comprehensive evaluation of practice, and should be transferable to other contexts. The findings suggest that SEA in Thailand currently partially achieves procedural, substantive, and transactive effectiveness. Achieving some elements of substantive effectiveness where practice is currently weak is considered to be particularly challenging, and also determinative in the achievement of legitimacy. Consequently, the majority of SEAs evaluated in this study failed to achieve legitimacy.

Keywords: Strategic environmental assessment (SEA), Effectiveness, procedural, substantive, transactive, legitimacy 


\section{Introduction: Setting the scene for SEA in Thailand}

Although Strategic Environmental Assessment (SEA) practice in Thailand dates back to 2005, SEA is still considered new in the Thai context, in terms of both implementation of a SEA system and actual practice (Yusook 2018). It is noted that the purposes of SEA application in Thailand have evolved from being a tool for shaping national strategic policies, plans, and programmes (in 2009), to an integrated tool in regional and sectoral development planning in 2011; then to a tiered decision-support tool culminating in projectlevel EIA (from 2015) (Sandang and Poboon 2018), and most recently a tool for national development planning in seven specified sectors and/or areas (in 2017 up to the time of writing) (Kumpa 2018, Office of the Prime Minister 2018, Sandang and Poboon 2018). Throughout this evolution, the implementation of SEA has remained discretionary.

The idea of SEA was initially introduced in Thailand in 2005 when the National Environment Board (NEB) established a SEA sub-committee to develop a SEA guideline and system for the country. The National Environment Board is given the authority, by the Enhancement and Conservation of National Environment Quality Act (NEQA) B.E.2535 (1992), to drive and approve matters regarding environmental quality management associated with policies, plans and pollution control. The SEA guideline was published in 2009 (ONEP 2009) and incorporated an expectation that environmental, economic, social, and technological considerations, in line with the Thai framing of sustainability, would be included (Kumpa 2018). Initially, the Office of the National Economic and Social Development Board (NESDB) (renamed as the Office of the National Economic and Social Development Council (NESDC) in December 2018), was asked to apply SEA on a nonmandatory basis when developing strategic policies and plans.

In 2011, the vision for SEA practice was expanded as government authorities with regional development roles were asked on a discretionary basis to integrate SEA with 
development planning, for example, water basin management, prior to the SEA findings being delivered to NEB (Kumpa 2018).

In 2015, integration of SEA into decision making at all strategic levels was proposed by the National Reform Council of Thailand (note this council was dissolved and duties transferred to the National Reform Steering Assembly in 2016). It was further proposed that the SEA findings should be applied within the EIA process (i.e. tiered levels of environmental assessment); allowing public participation in the SEA process to mitigate conflicts at lower levels; and the National Committee on Sustainable Development was suggested as the agency to be responsible for implementing this SEA system (The Secretariat of the House of Representatives 2015, p.15-16). According to the Prime Minister's Office (2018), SEA should be driven and integrated into national development planning over a three-year period. This system was proposed to apply on a sectoral and areabased system to: 1) transportation; 2) power development (power plants and petroleum); 3) river basin development; 4) special zone development; 5) urban planning; 6) industrial estate development; and 7) mega-projects development (Kumpa 2018, National Reform Steering Assembly 2017). However, the system was not mandatory and so practice has remained patchy.

In April 2018, the national reform plan on natural resources and environment was adopted (Office of the Prime Minister 2018). In this plan, SEA was one amongst many issues identified as requiring reform, ensuring that it be used to assess national development strategies to ensure sustainable development, and to help mitigate conflicts which may arise across the national strategies, e.g. between the sectoral and regional strategies. In order to drive the SEA mechanism and reform, a budget of 250 million Thai Baht (approximately 7.7 million US dollars) was planned to be invested during 2018-2020 in terms of: 1) establishing a SEA development framework \& building case studies; 2) SEA capacity 
building; 3) conducting SEA on national strategies (sectoral- \& area-based SEA); 4) exchanging SEA knowledge \& experience (i.e. conflict management, SEA system institutionalisation); 5) legislation improvement in terms of public participation requirements; 6) establishing institutional mechanisms for a SEA system; and 7) evaluation of the SEA system prior to developing a strategic plan for a SEA system in future (Office of the Prime Minister 2018, p.418-423). As it stands, then, SEA remains discretionary, but there is increasing practice and capacity development funding is now available.

By 26 June 2018, at least 27 SEAs had been conducted in Thailand (Kumpa 2018). These reflect limitations in applying SEA resulting from a lack of knowledge, capacity, experts, good databases, time and resources, limited SEA guidelines, lack of enforcement authority regarding the SEA system implementation, and the lack of legal mandate for SEA implementation (Amornpitakpun 2018, Kumpa 2018, Yusook 2018).

This research was motivated by a desire to understand the outcomes gained from the majority of SEA experience in Thailand to date. This is needed as there are limited studies investigating the outcomes of SEA in Thailand, apart from the SEA guideline as delivered by ONEP (2009) and the work of Wirutskulshai et al. (2011). Other relevant publications or reviews have analysed the SEA experience in Thailand as an overview, rather than investigating specific cases (for example, Environmental Protection Department 2007, Kumpa 2018, Sandang and Poboon 2018, Victor and Agamuthu 2014, World Bank 2006, Yusook 2018). Investigating and understanding the effectiveness of SEA in past cases can serve to identify specific strengths and weaknesses, and underpin recommendations for strengthening its capacity in supporting decision making towards sustainability. As such, this paper aims to evaluate the effectiveness of current SEA practice in Thailand.

More widely, there is a close match between the developing guidance and expectations of the Thai SEA system with international expectations for SEA, i.e. SEA 
should be integrated, sustainability-led, accountable, participative, and iterative (Fundingsland Tetlow and Hanusch 2012, International Association for Impact Assessment (IAIA) 2002). As such, the development and application of a framework to evaluate effectiveness of Thai practice potentially has relevance internationally.

The next section briefly reviews frameworks for evaluating impact assessment effectiveness, leading to the selection of the Pope et al. 2018 approach which was subsequently modified (Section 3) to evaluate the effectiveness of 14 Thai SEAs (Section 4). Key conclusions on current SEA practice in Thailand and some reflections on the utility of the modified effectiveness framework used in the research are provided in Section 5.

\section{Effectiveness framework for impact assessment}

Effectiveness frameworks for evaluating impact assessment have been developed by researchers over a period of time (e.g. Baker and McLelland 2003, Bond et al. 2013, Chanchitpricha and Bond 2013, Fundingsland Tetlow and Hanusch 2012, Sadler 1996, Theophilou et al. 2010). In the Thai context, the effectiveness of a potash mining health impact assessment and power plant environmental and health impact assessment were tested by a framework developed by Chanchitpricha (2012) and Chanchitpricha and Bond (2013), respectively, using the dimensions of procedural, substantive, transactive, and normative effectiveness. Subsequent application of the framework led to its further modification and development (Chanchitpricha and Bond 2018).

Bond et al. (2013), focussing on evaluation of sustainability assessment, added the dimensions of pluralism, and knowledge and learning to the existing four categories of effectiveness outlined in Chanchitpricha and Bond (2013). This framework was later tested by Pope et al. (2018) on a controversial SEA case in Australia in order to further examine the utility of the effectiveness dimensions. Their research led them to subsume the 
dimensions of pluralism and normative effectiveness into a 'legitimacy' dimension whereby "a legitimate process is one which all stakeholders agree is fair and which delivers an acceptable outcome for all parties" (p. 34). Bond et al. (2016) noted that legitimacy in impact assessment practice encompasses organisational legitimacy (incorporating the concepts of openness and transparency) and knowledge legitimacy (the knowledge or facts used in an assessment). Pope et al. (2018) also argued that some aspects of knowledge and learning underpin the mechanisms through which substantive effectiveness is delivered, whilst others (e.g. conceptual learning) are embedded in deliberate action delivered through procedural effectiveness. As such, they felt the knowledge and learning dimension of effectiveness was superfluous in practice. Thus, the Pope et al. (2018) framework forms the basis for evaluation of the Thai SEA cases.

\section{Methodology}

Bowen $(2009$, p.30) stated that "documents can be analysed as a way to verify findings or corroborate evidence from other sources". In this paper, documentary analysis was used to assess the effectiveness of Thai SEAs conducted/ published in the Thai context between 2001 and 2018. There is some uncertainty over the total number of SEAs that have been conducted at the time of writing, with the latest account being provided by Kumpa (2018), drawing on a 2017 report, to indicate that 27 had been prepared. Therefore, we know the total population of SEA cases in Thailand is at least 27. The lack of primary data obtained from other sources, e.g. via interviews and/or focus groups, is a limitation of this study contingent on the limited financial support available to conduct any field research.

The sampling strategy aimed to avoid selection bias through identification and evaluation of all SEA cases accessible online, supplemented with direct recruitment of otherwise inaccessible SEA reports from relevant authorities. Data collection for the SEA 
cases was performed on the basis of an online search, via Google Scholar along with the Google website, relevant authorities' websites and academic databases available to the researchers, which included Science Direct, and Taylor \& Francis online. The keywords: "Strategic environmental assessment" and Thailand", “ก า ร ป 5 ะ เ มิน สิ่ง แ ว ด ล้อ ม ระ ดับยุ ทธศา ส ต ร์",

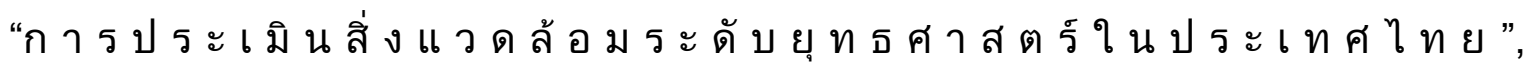
“คณะอนุกรรมการการประเมินสิ่งแวดล้อมระดับยุทธศาสตร์” (in Thai) were applied in each of the selected databases. Data for 11 SEA cases were identified online in various formats, such as, final reports, websites, journal articles and conference proceedings. As the SEA guideline, and knowledge on SEA practice, was limited at the time the cases were conducted, research-based SEAs are also included in this study (case nos. 1, 2, 3, 8, 9, 10, 12, and 13). An additional three cases were supplied upon request made to the relevant authority i.e. the relevant policy developers. This suggests that the accessibility of SEA findings online is relatively limited. Ultimately it was possible to assimilate a sample of around half of the full suite of SEA cases in Thailand (14 accessible out of at least 27 (Kumpa 2018) at the time of writing).

Details of the case studies are summarised in Table $\mathbf{1}$ including the available documentation, type of SEA and the methodology used in each SEA. 
Table 1 The sample of Thai SEA cases

\begin{tabular}{|c|c|c|c|}
\hline SEA Cases (SEA no.) & $\begin{array}{c}\text { Available } \\
\text { documentation }\end{array}$ & SEA type & Methodology used in SEA process \\
\hline $\begin{array}{l}\text { 1: SEA on shrimp farms in the southeast of } \\
\text { Thailand (Lindberg and Nyllander 2001) }\end{array}$ & $\begin{array}{l}\text { SEA report (Field } \\
\text { study/ as master } \\
\text { thesis) }\end{array}$ & $\begin{array}{l}\text { SEA conducted } \\
\text { expanded from } \\
\text { EIA concept; Back } \\
\text { casting SEA }\end{array}$ & $\begin{array}{l}\text { Qualitative approach (interviews, field observation, } \\
\text { literature review); no SEA guideline available. } \\
\text { Ordinal scaling technique was applied in assessing } \\
\text { the impacts of proposed alternatives. }\end{array}$ \\
\hline $\begin{array}{l}\text { 2: Developing public policy process and } \\
\text { alternatives by using SEA: a case study of } \\
\text { Solid Waste Management in Thailand } \\
\text { (Haesakul et al. 2007) }\end{array}$ & $\begin{array}{l}\text { SEA full report } \\
\text { (research findings) }\end{array}$ & $\begin{array}{l}\text { Policy SEA (relied } \\
\text { on decision-centred } \\
\text { model) - research } \\
\text { based SEA }\end{array}$ & $\begin{array}{l}\text { Qualitative approach (participatory research); no } \\
\text { SEA guideline available. }\end{array}$ \\
\hline $\begin{array}{l}\text { 3: Management of Yom River Basin by } \\
\text { using SEA (Settasirote et al. 2007) }\end{array}$ & $\begin{array}{l}\text { SEA full report } \\
\text { (research findings) }\end{array}$ & $\begin{array}{l}\text { Area based SEA - } \\
\text { research based }\end{array}$ & $\begin{array}{l}\text { Qualitative approach (documentary analysis, } \\
\text { experts \& stakeholder participation); no SEA } \\
\text { guideline available but combing SEA concept with } \\
\text { PROACT (rational decision-making) model }\end{array}$ \\
\hline $\begin{array}{l}\text { 4: SEA of Tha Chin River Basin for } \\
\text { sustainable development (ONEP 2011) }\end{array}$ & $\begin{array}{l}\text { SEA Full report/ } \\
\text { summary report }\end{array}$ & Area based SEA & $\begin{array}{l}\text { Mainly qualitative approach (documentary } \\
\text { analysis, experts \& stakeholder participation); } \\
\text { Based on SEA guideline (ONEP 2009) combined } \\
\text { with PSIR (Pressure-State-Impact-Response) } \\
\text { concept and Multi Criteria Analysis (MCA), SEA } \\
\text { conceptual framework provided }\end{array}$ \\
\hline $\begin{array}{l}\text { 5: SEA of Mueang Rayong district and the } \\
\text { adjacent zones (Department of Industrial } \\
\text { Works 2012) }\end{array}$ & $\begin{array}{l}\text { SEA Full report/ } \\
\text { Summary report }\end{array}$ & $\begin{array}{l}\text { Sectoral based } \\
\text { SEA }\end{array}$ & $\begin{array}{l}\text { Mainly qualitative approach (documentary } \\
\text { analysis, experts \& stakeholder participation); } \\
\text { Related to SEA guideline (ONEP 2009) combined } \\
\text { with GIS based map overlay method and MCA } \\
\text { technique, SEA conceptual framework provided }\end{array}$ \\
\hline $\begin{array}{l}\text { 6: SEA for Potash Mining Development } \\
\text { (Department of Primary Industries and } \\
\text { Mines 2012) }\end{array}$ & $\begin{array}{l}\text { Webpage only; not } \\
\text { able to access full } \\
\text { final report }\end{array}$ & $\begin{array}{l}\text { Linked with EIA } \\
\text { based SEA and } \\
\text { Policy SEA (relied } \\
\text { on decision-centred } \\
\text { model) - Sectoral } \\
\text { based SEA }\end{array}$ & $\begin{array}{l}\text { Mainly qualitative approach (documentary } \\
\text { analysis, experts \& stakeholder participation); } \\
\text { Related to SEA guideline (ONEP 2009) SEA } \\
\text { conceptual framework provided. }\end{array}$ \\
\hline $\begin{array}{l}\text { 7: SEA in adjacent zones of Suvarnabhumi } \\
\text { Airport (Airports of Thailand Public } \\
\text { Company Limited 2013) }\end{array}$ & $\begin{array}{l}\text { SEA Full report/ } \\
\text { summary report }\end{array}$ & $\begin{array}{l}\text { Policy SEA (relied } \\
\text { on decision-centred } \\
\text { model) }\end{array}$ & $\begin{array}{l}\text { Mainly qualitative approach (documentary } \\
\text { analysis, stakeholder participation); SEA } \\
\text { conducted following ONEP's guideline (2009) } \\
\text { combined with GIS based map, expert judgement, } \\
\text { Trend analysis, extrapolation, and adaptive MCA } \\
\text { technique. }\end{array}$ \\
\hline $\begin{array}{l}\text { 8: SEA of Kanchanaburi special economic } \\
\text { zone (SEZ) development strategy (Putta } \\
\text { and Poboon 2015) }\end{array}$ & Published paper & $\begin{array}{l}\text { Regional based } \\
\text { SEA (Research } \\
\text { findings) - Area } \\
\text { based SEA }\end{array}$ & $\begin{array}{l}\text { Mainly qualitative approach (documentary } \\
\text { analysis, In-depth interviews, expert judgement, } \\
\text { scenario analysis, MCA- analytical hierarchy } \\
\text { process }\end{array}$ \\
\hline $\begin{array}{l}\text { 9: SEA of special economic zone } \\
\text { development strategy, Chiang Saen district, } \\
\text { Chiang Rai province (Tengsakul and } \\
\text { Poboon 2015) }\end{array}$ & Published paper & $\begin{array}{l}\text { Regional based } \\
\text { SEA }\end{array}$ & $\begin{array}{l}\text { Mainly qualitative approach (documentary } \\
\text { analysis, field observation, stakeholder interviews, } \\
\text { analytical hierarchy process, MCA }\end{array}$ \\
\hline $\begin{array}{l}\text { 10: SEA: A case study of the special } \\
\text { economic zone in Chiang Khong district, } \\
\text { Chiang Rai province (Uttano and Poboon } \\
\text { 2018) }\end{array}$ & Published paper & $\begin{array}{l}\text { Regional based } \\
\text { SEA }\end{array}$ & $\begin{array}{l}\text { Mainly qualitative approach (documentary } \\
\text { analysis, observation, structured interviews, expert } \\
\text { judgement, scenario analysis) }\end{array}$ \\
\hline $\begin{array}{l}\text { 11: The Study of SEA for the Development } \\
\text { of the Southern Coastal Areas (Office of } \\
\text { Transport and Traffic Policy and Planning } \\
\text { 2016) }\end{array}$ & $\begin{array}{l}\text { SEA Full report/ } \\
\text { Summary report }\end{array}$ & $\begin{array}{l}\text { Regional based } \\
\text { SEA (relied on } \\
\text { decision-centred } \\
\text { model) }\end{array}$ & $\begin{array}{l}\text { Mainly qualitative approach documentary analysis, } \\
\text { stakeholder participation); SEA conducted } \\
\text { following ONEP's guideline (2009) }\end{array}$ \\
\hline $\begin{array}{l}\text { 12: Assessment of Potential Industrial } \\
\text { Estate Site using SEA approach: Case } \\
\text { Study of Khon Khaen Province (in Thai) } \\
\text { (Joomlee and Wirojanagud 2016) }\end{array}$ & $\begin{array}{l}\text { Conference } \\
\text { proceeding/ } \\
\text { Findings of } \\
\text { research }\end{array}$ & $\begin{array}{l}\text { Sectoral based } \\
\text { SEA (research } \\
\text { findings) }\end{array}$ & $\begin{array}{l}\text { Mainly qualitative approach (documentary } \\
\text { analysis); GIS based map, expert judgement, MCA } \\
\text { technique. }\end{array}$ \\
\hline
\end{tabular}




\begin{tabular}{|l|l|l|l|}
\hline \multicolumn{1}{|c|}{ SEA Cases (SEA no.) } & \multicolumn{1}{c|}{$\begin{array}{c}\text { Available } \\
\text { documentation }\end{array}$} & SEA type & Methodology used in SEA process \\
\hline $\begin{array}{l}\text { 13: SEA for Tourism: A Case study of } \\
\text { Tourism Group Area of Phu Kradueng, } \\
\begin{array}{l}\text { Nong Hin and Phu Luang, Loei Province, } \\
\text { Thailand (Namee and Rooachanakanan } \\
\text { 2016) }\end{array}\end{array}$ & $\begin{array}{l}\text { Conference } \\
\text { proceeding/ } \\
\text { Findings of SEA } \\
\text { scoping }\end{array}$ & Issue-based SEA & $\begin{array}{l}\text { Mainly qualitative approach (documentary } \\
\text { analysis, expert judgements using Delphi technique }\end{array}$ \\
$\begin{array}{l}\text { 14: SEA for ecosystem services in the Gulf } \\
\text { of Thailand (the east coastal zone) (ONEP } \\
\text { 2016) }\end{array}$ & $\begin{array}{l}\text { SEA Full report/ } \\
\text { Summary report }\end{array}$ & $\begin{array}{l}\text { Regional based } \\
\text { SEA }\end{array}$ & $\begin{array}{l}\text { Documentary analysis of the relevant policies, and } \\
\text { participation with relevant authorities. }\end{array}$ \\
\hline
\end{tabular}

Whilst evidence of practice relied on documentary analysis, evaluation of that practice is based on the application of best-practice criteria. This is a tried and tested approach for evaluation of impact assessment (e.g. Sadler, 1996; Lee et al. 1999). Pope et al. (2018) developed dimensions at an aggregate level whereby those undertaking the evaluations apply judgements to overarching questions, one for each dimension. Chanchitpricha and Bond $(2013 ; 2015)$ had previously disaggregated the procedural, substantive and transactive dimensions of effectiveness into a series of sub-criteria, facilitating a more detailed understanding of specific practice. With some amendments of the framework, we supplemented these through the development of new legitimacy effectiveness sub-criteria, thereby completing a full framework of effectiveness best practice criteria based on the Pope et al. 2018 conceptualisation of effectiveness.

The legitimacy sub-criteria are based on Bond et al. (2018) who asserted, based on Suchman (1995) and Cashmore and Wejs (2014), that organisational legitimacy for IA is based on the 'openness and transparency' of the impact assessment process, along with 'equity and social justice'; they also argued that the 'distribution of powers and responsibility' are key elements contributing to the level of legitimacy (Merad and Trump 2018); thus, these provide the first two sub-criteria (Table 2). These sub-criteria encapsulate aspects of public consultation and its use to inform decision-making that Chanchitpricha and Bond (2013) had included as substantive effectiveness criteria. Bond et al. (2018) also conceptualised four aspects of knowledge legitimacy: 'knowledge accuracy' (is the evidence base applied in the impact assessment process reliable?); 'knowledge restriction' 
(are findings from the scoping stage overlooked?); 'knowledge diffusion' (can the full range of evidence be accessed?); and 'knowledge spectrum' (is informal knowledge integrated in the impact assessment?). These four criteria complete the sub-criteria for the legitimacy dimension of effectiveness in Table 2. Bond et al. (2018) were clear that developing approaches for examining aspects of knowledge legitimacy remains a challenge. Specifically, 'knowledge restriction', as conceptualised, refers to selective editing or withholding of evidence. This might be reflected in an inappropriately narrow scope for an SEA, or failure to draw on evidence which exists. Documentary analysis will not identify such premeditated acts that have already influenced what is presented in a report. This limits the extent to which knowledge restriction can properly be identified and is a concrete example of the limitations of a documentary-based analysis.

Using the criteria detailed in Table 2, and following the approach taken by Wood (2003) and Theophilou et al. (2010), we considered whether each criterion has been met by responding with the answer of "Y" (yes - fully met), "N" (no - not met at all), "P" (partially met)", "?" (unclear whether met), or "N/A" (the question does not apply), justified based on the evidence we had to hand (i.e. relevant documents, reports, reviews - see the notes for Table 3).

Thus, we apply the most recent conceptualisation of effectiveness, verified in practice, whilst applying more detailed criteria capable of providing a richer understanding of practice. We note here that some elements of procedural effectiveness criteria investigated in this paper correspond to 'context effectiveness' as defined by Wang et al. (2012), and some other scholars in this special issue. 


\section{Table 2 Adopted effectiveness criterial framework for SEA evaluation}

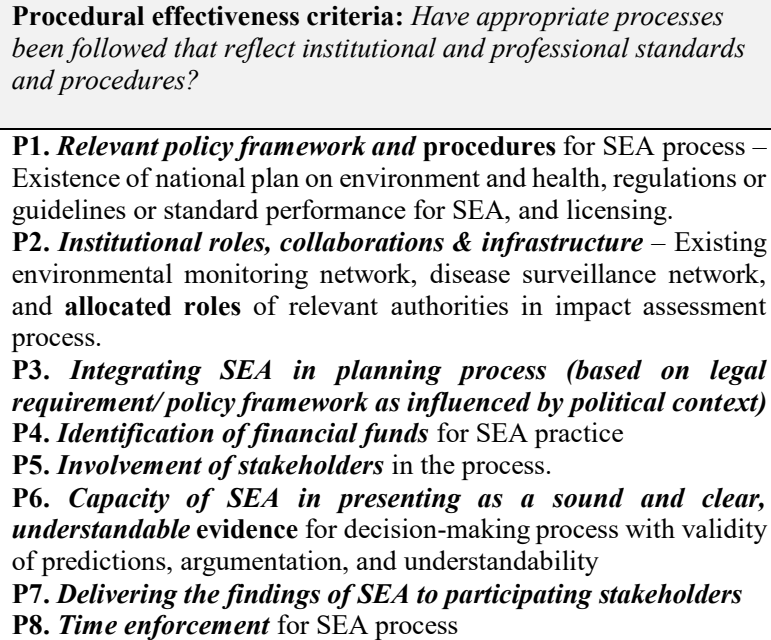

P1. Relevant policy framework and procedures for SEA process Existence of national plan on environment and health, regulations or guidelines or standard performance for SEA, and licensing.

P2. Institutional roles, collaborations \& infrastructure - Existing environmental monitoring network, disease surveillance network, and allocated roles of relevant authorities in impact assessment process.

P3. Integrating SEA in planning process (based on legal requirement/policy framework as influenced by political context) P4. Identification of financial funds for SEA practice

P5. Involvement of stakeholders in the process.

P6. Capacity of SEA in presenting as a sound and clear, understandable evidence for decision-making process with validity of predictions, argumentation, and understandability

P7. Delivering the findings of SEA to participating stakeholders

P8. Time enforcement for SEA process

Substantive effectiveness criteria: To what extent does the assessment lead to changes in process, actions, learning or outcomes?

S1.Regulatory framework for implementing SEA in decision-making. S2.Incorporation of proposed changes - most or all proposals for changes or additions to the draft emanating from the SEA were taken into account in the final version of the project/ or programme related to project development.

S3. Informed decision-making - the use of mandatory documents as part of the SEA process, with continuous dialogue between the parties involved in the process of informed decisions on the final version of project development

S4. Close collaboration - there was communication and a high level of collaboration between those producing the SEA, and project developer. S5. Parallel development - the SEA and the project/ programme developed alongside one other with considerable cross-cutting between the processes.

S6. Early start - the SEA process was initiated at the very first stages of policy/ programme/ plan development.

S7. Institutional and other benefits - there is strong evidence of better department relations, development of otherwise absent expertise, learning, new partnerships and better public-private-voluntary sector communication as a result of SEA when implementing in decision making.

Transactive effectiveness criteria: To what extent, and by whom, is the outcome of conducting the assessment considered to be worth the time and cost involved?

T1. Time - SEA was carried out within a reasonable time frame without undue delay or within a very short time period (as compared to old ex-ante mechanism, where applicable).

T2. Financial resources - carrying out the SEA did not entail excessive spending

T3. Skills - the acquiring of skills and personnel required for the SEA did not contribute a big burden and these were easily accessible. T4. Specification of roles - responsibilities were clearly defined and allocated and tasks were undertaken by the most appropriate subjects.

T5. Availability of human resources

Legitimacy of SEA practice (Organisational \& Knowledge): Was the assessment process perceived to be legitimate by a wide range of stakeholders

L1. Openness, transparency \& equity of SEA process - a wide range of stakeholders were satisfied with the SEA practice, findings, proposed options, and decisions

L2. Distribution of powers and responsibility regarding $S E A$ practice \& system - there is evidence that powers were appropriately balanced among relevant authorities having key roles in facilitating/ driving SEA practice and implementation, for example, policy/ plan makers, assigned expert panels, assign SEA development committee, other relevant stakeholders.

L3. Knowledge accuracy - the evidence base applied in SEA process was reliable.

L4. Knowledge integration - all key findings from SEA practice including findings from scoping stage of SEA were utilised in subsequent stages/decisions

L5. Knowledge diffusion - the full range of evidence regarding the SEA practice was able to be accessed

L6. Knowledge spectrum - both formal and informal knowledge was integrated in the SEA process.

Sources: framework adapted for this paper based on Chanchitpricha and Bond (2013, 2015, 2018), Pope et al. (2018, p.43), Bond et al. (2018), and Merad and Trump (2018)

\section{Evaluating the effectiveness of Thai SEA practice}

We investigated the effectiveness of the reviewed cases (Table 1) based on the criteria 
framework in Table 2. Although it appears that the SEAs partially or fully meet most effectiveness criteria (Table 3; Figure 1), there are exceptions as discussed in sections 4.1 to 4.4

Figure 1 presents an overview of the effectiveness of SEA practice in Thailand based on procedural, substantive, transactive effectiveness and legitimacy.

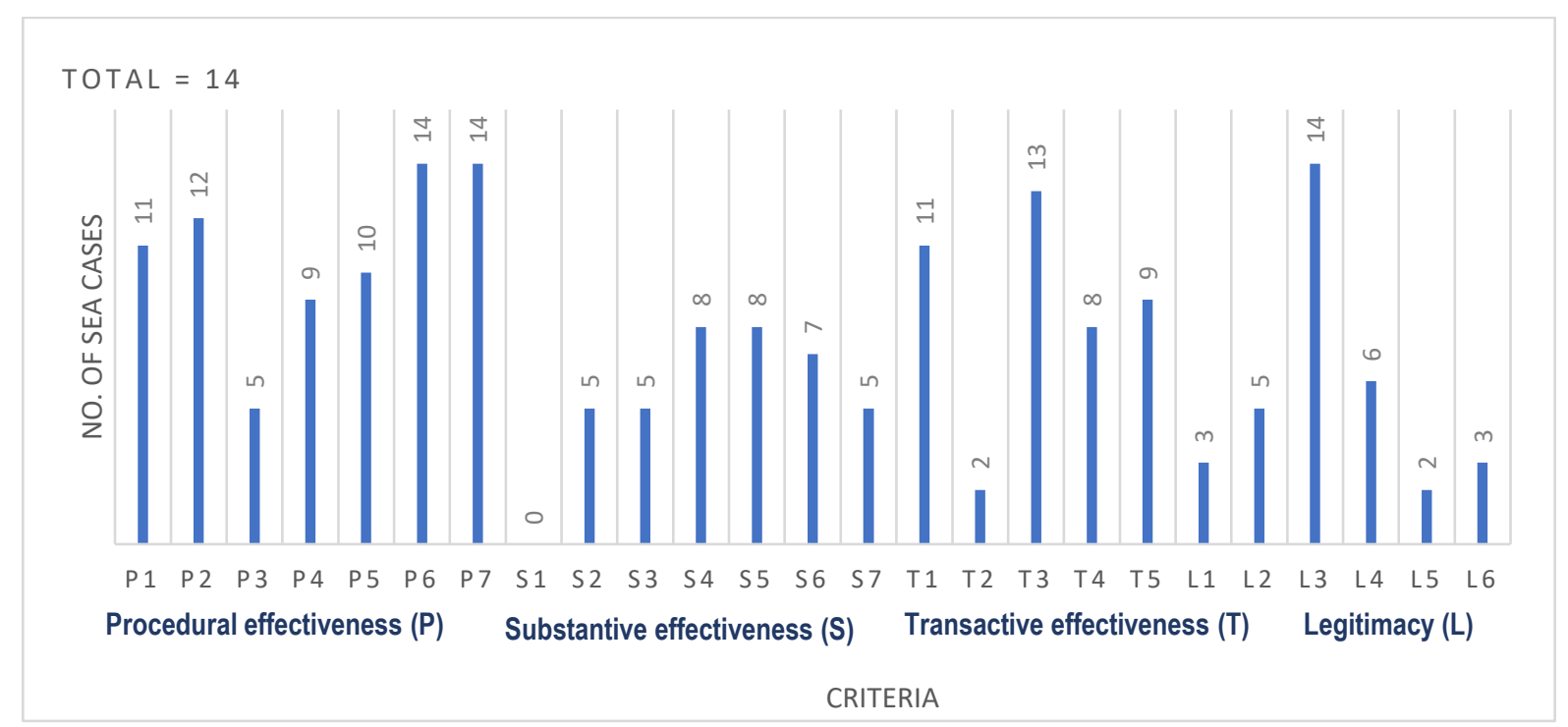

Figure 1 Number of SEA cases which partially (P) or fully (Y) meet sub-criteria on procedural, substantive, transactive effectiveness and legitimacy 
Table 3 The overview of SEA Effectiveness in Thai context based on documentary analysis

\begin{tabular}{|c|c|c|c|c|c|c|c|c|c|c|c|c|c|c|c|c|}
\hline & \multirow{2}{*}{$\begin{array}{l}\text { Effectiveness category and criterion } \\
\text { Procedural: Have appropriate processes } \\
\text { been followed that reflect institutional and } \\
\text { professional standards \& procedures? }\end{array}$} & \multicolumn{14}{|c|}{ Criterion met } & \multirow[b]{2}{*}{ Comments/ discussion } \\
\hline & & $\begin{array}{l}\text { SEA } 1 \\
2001\end{array}$ & $\begin{array}{l}\text { SEA 2 } \\
2007\end{array}$ & $\begin{array}{l}\text { SEA 3 } \\
2007\end{array}$ & $\begin{array}{l}\text { SEA } 4 \\
2011\end{array}$ & $\begin{array}{l}\text { SEA } 5 \\
2012\end{array}$ & $\begin{array}{l}\text { SEA } 6 \\
2012\end{array}$ & $\begin{array}{l}\text { SEA } 7 \\
2013\end{array}$ & $\begin{array}{l}\text { SEA 8 } \\
2015\end{array}$ & $\begin{array}{l}\text { SEA 9 } \\
2015\end{array}$ & $\begin{array}{l}\text { SEA } 10 \\
2018\end{array}$ & $\begin{array}{l}\text { SEA } 11 \\
20 \\
\end{array}$ & $\begin{array}{l}\text { SEA } 12 \\
2016\end{array}$ & $\begin{array}{l}\text { SEA } 13 \\
2016\end{array}$ & $\begin{array}{l}\text { SEA } 14 \\
2016\end{array}$ & \\
\hline \multirow[t]{3}{*}{$P 1$} & \multicolumn{16}{|l|}{$\begin{array}{l}\text { Relevant policy framework and } \\
\text { procedures for SEA process }\end{array}$} \\
\hline & \multirow{2}{*}{$\begin{array}{l}\text { 1.1 Existence of governmental policy } \\
\text { framework and national plan concerning } \\
\text { SEA } \\
\text { 1.2 Existence of regulations in relation to } \\
\text { guidelines or standard performance for } \\
\text { SEA process, and licensing }\end{array}$} & $\mathrm{N}$ & $\mathrm{N}$ & $\mathrm{N}$ & $\mathrm{P}$ & $\mathrm{P}$ & $\mathrm{P}$ & $\mathrm{P}$ & $\mathrm{P}$ & $\mathrm{P}$ & $P$ & $\mathrm{P}$ & $\mathrm{P}$ & $\mathrm{P}$ & $\mathrm{P}$ & 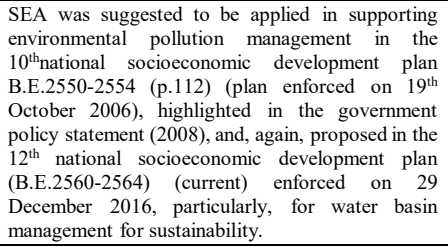 \\
\hline & & $\mathrm{N}$ & $\mathrm{N}$ & $\mathrm{N}$ & $\mathrm{N}$ & $\mathrm{N}$ & $\mathrm{N}$ & $\mathrm{N}$ & $\mathrm{N}$ & $\mathrm{N}$ & $\mathrm{N}$ & $\mathrm{N}$ & $\mathrm{N}$ & $\mathrm{N}$ & $\mathrm{N}$ & $\begin{array}{l}\text { Although SEA guideline was provided by ONEP } \\
\text { in 2009, explicit legislation for SEA } \\
\text { implementation has not been enforced to date. } \\
\text { Therefore, all cases are considered failing meeting } \\
\text { this criterion. }\end{array}$ \\
\hline \multirow[t]{3}{*}{$P 2$} & \multirow{3}{*}{$\begin{array}{l}\text { Institutional Characteristics } \\
2.1 \quad \text { Existing environmental monitoring network } \\
2.2 \text { Environmental surveillance network } \\
2.3 \text { Collaborations between relevant } \\
\text { sectors }\end{array}$} & $\mathrm{N}$ & $\mathrm{N}$ & $\mathrm{P}$ & $\mathrm{P}$ & $\mathrm{P}$ & $\mathrm{P}$ & Y & $\mathrm{P}$ & $\mathrm{P}$ & $\mathrm{P}$ & $\mathrm{P}$ & $\mathrm{P}$ & ? & $\mathrm{P}$ & \multirow{3}{*}{ Assessed based on the reviewed case evidence } \\
\hline & & $\mathrm{N}$ & $\mathrm{N}$ & $\mathrm{P}$ & $\mathrm{P}$ & $\mathrm{P}$ & $\mathrm{P}$ & $\mathrm{Y}$ & $\mathrm{P}$ & $\mathrm{P}$ & $\mathrm{P}$ & $\mathrm{P}$ & $\mathrm{P}$ & $?$ & $\mathrm{P}$ & \\
\hline & & $\mathrm{N}$ & $\mathrm{P}$ & $\mathrm{P}$ & $\mathrm{Y}$ & $\mathrm{P}$ & $\mathrm{P}$ & $\mathrm{Y}$ & $\mathrm{P}$ & $\mathrm{P}$ & $\mathrm{P}$ & $\mathrm{P}$ & $\mathrm{P}$ & $?$ & $\mathrm{P}$ & \\
\hline$P 3$ & $\begin{array}{l}\text { Integrating SEA in planning process of } \\
\text { national development policy framework }\end{array}$ & $\mathrm{N}$ & $\mathrm{P}$ & $?$ & $\mathrm{Y}^{* 4 \mathrm{P} 3}$ & $\mathrm{P}$ & ? & Y & $?$ & ? & ? & $\mathrm{P}$ & ? & $\mathrm{N}$ & Y & $\begin{array}{l}\text { Minority of cases presented the evidence in the } \\
\text { integrating SEA in planning process }\end{array}$ \\
\hline \multirow[t]{3}{*}{$P 4$} & \multirow{3}{*}{$\begin{array}{l}\text { Identification of financial funds for SEA } \\
\text { practice } \\
4.1 \text { Funding for conducting SEA } \\
\text { 4.2 Funding for conducting relevant research } \\
\text { to improve SEA practice \& guideline in } \\
\text { Thailand }\end{array}$} & & & & & & & & & & & & & & & \multirow{3}{*}{$\begin{array}{l}\text { Analysed regarding financial support for each case, } \\
\text { research funding is provided based on national } \\
\text { policy in each fiscal year for academic researchers } \\
\text { regarding their interest/ expertise, but not directly } \\
\text { for }(4.2)\end{array}$} \\
\hline & & Y & Y & Y & Y & Y & Y & Y & $\mathrm{N}$ & $\mathrm{N}$ & $\mathrm{N}$ & Y & $?$ & $?$ & Y & \\
\hline & & $\mathrm{N}$ & Y & Y & $\mathrm{N}$ & $\mathrm{N}$ & $\mathrm{N}$ & $\mathrm{N}$ & $?$ & $?$ & $?$ & $\mathrm{P}$ & $?$ & ? & $\mathrm{N}$ & \\
\hline$P 5$ & $\begin{array}{l}\text { Involvement of stakeholders in the SEA } \\
\text { process }\end{array}$ & $\mathrm{N}$ & Y & Y & Y & Y & Y & Y & $\mathrm{N}$ & $P$ & $\mathrm{~N}$ & Y & Y & $\mathrm{N}$ & $\mathrm{P}$ & $\begin{array}{l}\text { Analysed based on public participation techniques } \\
\text { applied, and the ranges of stakeholders took part in } \\
\text { the SEA processes. }\end{array}$ \\
\hline$P 6$ & $\begin{array}{l}\text { Capacity of SEA to present a sound and clear } \\
\text { understandable evidence for the decision-making } \\
\text { process with valid prediction and argumentation }\end{array}$ & $\mathrm{P}$ & $\mathrm{P}$ & $\mathrm{P}$ & Y & $\mathrm{Y}$ & $\mathrm{P}$ & Y & $\mathrm{P}$ & Y & $\mathrm{Y}$ & $\mathrm{Y}$ & $\mathrm{P}$ & ? & Y & Assessed based on the reviewed case evidence \\
\hline$P 7$ & $\begin{array}{l}\text { Delivering the findings of SEA to } \\
\text { participating stakeholders }\end{array}$ & $P$ & $P$ & $\mathrm{P}$ & $\mathrm{P}$ & $\mathrm{P}$ & $\mathrm{P}$ & $\mathrm{P}$ & $\mathrm{P}$ & $\mathrm{P}$ & $\mathrm{P}$ & Y & $\mathrm{P}$ & $\mathrm{P}$ & $\mathrm{P}$ & $\begin{array}{l}\text { Assessed based on accessibility of the SEA } \\
\text { findings i.e. websites, online database, and key } \\
\text { relevant authorities }\end{array}$ \\
\hline$P 8$ & Time enforcement for SEA process & N/A & N/A & N/A & N/A & N/A & N/A & N/A & N/A & N/A & N/A & N/A & N/A & N/A & N/A & $\begin{array}{l}\text { As SEA was not mandatory, so, this criterion is } \\
\text { excluded in this assesssment }\end{array}$ \\
\hline & Substantive: & & & & & & & & & & & & & & & \\
\hline
\end{tabular}




\begin{tabular}{|c|c|c|c|c|c|c|c|c|c|c|c|c|c|c|c|c|}
\hline & $\begin{array}{l}\text { To what extent does the assessment lead to } \\
\text { changes in process, actions, learning or } \\
\text { outcomes? }\end{array}$ & $\begin{array}{l}\text { SEA } 1 \\
2001\end{array}$ & $\begin{array}{l}\text { SEA 2 } \\
2007\end{array}$ & $\begin{array}{l}\text { SEA 3 } \\
2007\end{array}$ & $\begin{array}{l}\text { SEA } 4 \\
2011\end{array}$ & $\begin{array}{l}\text { SEA 5 } \\
2012\end{array}$ & $\begin{array}{l}\text { SEA 6 } \\
2012\end{array}$ & $\begin{array}{l}\text { SEA 7 } \\
2013\end{array}$ & $\begin{array}{l}\text { SEA 8 } \\
2015\end{array}$ & $\begin{array}{l}\text { SEA 9 } \\
2015\end{array}$ & $\begin{array}{l}\text { SEA } 10 \\
2018\end{array}$ & $\begin{array}{l}\text { SEA } 11 \\
2016\end{array}$ & $\begin{array}{l}\text { SEA } 12 \\
2016\end{array}$ & $\begin{array}{l}\text { SEA } 13 \\
2016\end{array}$ & $\begin{array}{l}\text { SEA } 14 \\
2016\end{array}$ & Comments/ discussion \\
\hline$S 1$ & $\begin{array}{l}\text { Regulatory framework for } \\
\text { implementing SEA in decision-making }\end{array}$ & $\mathrm{N}$ & $\mathrm{N}$ & $\mathrm{N}$ & $\mathrm{N}$ & $\mathrm{N}$ & $\mathrm{N}$ & $\mathrm{N}$ & $\mathrm{N}$ & $\mathrm{N}$ & $\mathrm{N}$ & $\mathrm{N}$ & $\mathrm{N}$ & $\mathrm{N}$ & $\mathrm{N}$ & $\begin{array}{l}\text { There is a policy framework, but not yet a } \\
\text { regulatory framework available at the time of the } \\
\text { SEA cases conducted }\end{array}$ \\
\hline$S 2$ & $\begin{array}{l}\text { Incorporation of proposed changes - } \\
\text { SEA was taken into account in the final } \\
\text { version of the policy/ plan }\end{array}$ & $?$ & $\mathrm{P}^{* 2 \mathrm{~S} 2}$ & ? & ? & $\mathrm{P}^{* 5 \mathrm{~S} 2}$ & ? & $\mathrm{P}$ & $\mathrm{N}$ & $\mathrm{N}$ & $\mathrm{N}$ & Y & $\mathrm{N} / \mathrm{A}$ & $\mathrm{N} / \mathrm{A}$ & $\mathrm{Y}$ & $\begin{array}{l}\text { The majority of cases were not referred to in } \\
\text { relevant policy/ plan making explicitly }\end{array}$ \\
\hline$S 3$ & Informed decision-making & N/A & N/A & $\mathrm{N} / \mathrm{A}$ & $\mathrm{P}^{* 4 \mathrm{~S} 3}$ & $\mathrm{P}^{* 5 \mathrm{~S} 3}$ & $\mathrm{~N}$ & $\mathrm{P}$ & $\mathrm{N}$ & $\mathrm{N}$ & $\mathrm{N}$ & $P$ & $\mathrm{~N} / \mathrm{A}$ & $\mathrm{N} / \mathrm{A}$ & $\mathrm{P}$ & $\begin{array}{l}\text { SEA findings delivered by policy maker (ONEP), } \\
\text { regulator(DIW, OTP) }\end{array}$ \\
\hline$S 4$ & Close collaboration & $?$ & $\mathrm{P}$ & $\mathrm{P}$ & $\mathrm{P}$ & $\mathrm{P}$ & $\mathrm{P}$ & $\mathrm{P}$ & $\mathrm{N}$ & $\mathrm{N}$ & $\mathrm{N}$ & Y & $\mathrm{N} / \mathrm{A}$ & $\mathrm{N} / \mathrm{A}$ & $\bar{Y}$ & $\begin{array}{l}\text { Analysed based on the information of relevant } \\
\text { authorities providing \& conducting the SEAs i.e. } \\
\text { policy makers, regulators, consultants }\end{array}$ \\
\hline$S 5$ & Parallel development & ? & ? & ? & $\mathrm{P}$ & $\mathrm{P}$ & $\mathrm{P}$ & $\mathrm{P}$ & $\mathrm{N}$ & $\mathrm{N}$ & $\mathrm{N}$ & $\mathrm{P}$ & $\mathrm{P}$ & $\mathrm{P}$ & $\mathrm{Y}$ & \multirow{3}{*}{ Assessed based on the reviewed case evidence } \\
\hline$S 6$ & Early start & N/A & N/A & $\mathrm{N} / \mathrm{A}$ & $\mathrm{P}$ & $\mathrm{P}$ & $\mathrm{N}$ & $\mathrm{P}$ & $\mathrm{N}$ & $\mathrm{N}$ & $\mathrm{N}$ & $\mathrm{P}$ & $\mathrm{P}$ & $\mathrm{P}$ & Y & \\
\hline$S 7$ & Institutional and other benefits & & $?$ & $\mathrm{P}$ & $?$ & $\mathrm{P}$ & $\mathrm{P}$ & $\mathrm{P}$ & $\mathrm{N}$ & $\mathrm{N}$ & $\mathrm{N}$ & $\mathrm{P}$ & $\mathrm{N} / \mathrm{A}$ & $\mathrm{N} / \mathrm{A}$ & $\mathrm{P}$ & \\
\hline & $\begin{array}{l}\text { Transactive: To what extent, is the } \\
\text { outcome of conducting the assessment } \\
\text { considered to be worth the time and cost } \\
\text { involved? }\end{array}$ & $\begin{array}{l}\text { SEA } 1 \\
2001\end{array}$ & $\begin{array}{l}\text { SEA } 2 \\
2007\end{array}$ & $\begin{array}{l}\text { SEA } 3 \\
2007\end{array}$ & $\begin{array}{l}\text { SEA } 4 \\
2011 \\
\end{array}$ & $\begin{array}{l}\text { SEA } 5 \\
2012 \\
\end{array}$ & $\begin{array}{l}\text { SEA } 6 \\
2012\end{array}$ & $\begin{array}{l}\text { SEA } 7 \\
2013\end{array}$ & $\begin{array}{l}\text { SEA } 8 \\
2015\end{array}$ & $\begin{array}{l}\text { SEA 9 } \\
2015\end{array}$ & $\begin{array}{l}\text { SEA } 10 \\
2018\end{array}$ & $\begin{array}{l}\text { SEA } 11 \\
2016\end{array}$ & $\begin{array}{l}\text { SEA } 12 \\
2016\end{array}$ & $\begin{array}{l}\text { SEA } 13 \\
2016\end{array}$ & $\begin{array}{l}\text { SEA } 14 \\
2016\end{array}$ & Comments/ discussion \\
\hline$T 1$ & Time & $\mathrm{P}$ & $\mathrm{Y}$ & $\mathrm{Y}$ & $P$ & $\mathrm{P}$ & $\mathrm{N}$ & $P$ & $?$ & $?$ & $?$ & $\mathrm{Y}$ & $P$ & $?$ & $P$ & \multirow{2}{*}{$\begin{array}{l}\text { *financial resources invested by the government } \\
\text { authorities, with regulations in hiring and advised } \\
\text { time frame for SEA process }\end{array}$} \\
\hline$T 2$ & Financial resources & $?$ & $\mathrm{P}$ & $\mathrm{P}$ & $\mathrm{P}$ & $\mathrm{P} \quad *$ & $\mathrm{P} \quad *$ & $\mathrm{P} \quad *$ & $\mathrm{~N}$ & $\mathrm{~N}$ & $\mathrm{~N}$ & $\mathrm{P} \quad *$ & $\mathrm{~N}$ & $?$ & $\mathrm{P} \quad *$ & \\
\hline$T 3$ & Skills \& personnel & $\mathrm{P}$ & $\mathrm{P}$ & $\mathrm{P}$ & $\mathrm{Y}$ & $\mathrm{P}$ & $?$ & $\mathrm{Y}$ & $\mathrm{P}$ & $\mathrm{P}$ & $\mathrm{P}$ & $\mathrm{Y}$ & $\mathrm{P}$ & $\mathrm{P}$ & $\mathrm{Y}$ & \multirow{3}{*}{$\begin{array}{l}\text { Analysed based the lists of team members } \\
\text { conducting SEA, and lesson learned from SEA } \\
\text { process as noted in some cases in this study }\end{array}$} \\
\hline$T 4$ & Specification of roles & $?$ & $\mathrm{P}$ & $\mathrm{P}$ & $\mathrm{P}$ & $\mathrm{P}$ & $?$ & $\mathrm{Y}$ & $?$ & $?$ & $?$ & $\mathrm{Y}$ & $?$ & $?$ & $\mathrm{Y}$ & \\
\hline \multirow[t]{2}{*}{$T 5$} & Availability of human resources & $\mathrm{P}$ & $\mathrm{N}$ & $\mathrm{P}$ & $\mathrm{P}$ & $\mathrm{P}$ & $\mathrm{P}$ & $\mathrm{P}$ & $?$ & $?$ & $?$ & $\mathrm{Y}$ & $?$ & $?$ & $\mathrm{Y}$ & \\
\hline & $\begin{array}{l}\text { Legitimacy: Was the assessment process } \\
\text { perceived to be legitimate by a wide range } \\
\text { of stakeholders? (Organisational legitimacy } \\
\text { and knowledge legitimacy) }\end{array}$ & $\begin{array}{l}\text { SEA } 1 \\
2001\end{array}$ & $\begin{array}{l}\text { SEA 2 } \\
2007\end{array}$ & $\begin{array}{l}\text { SEA 3 } \\
2007\end{array}$ & $\begin{array}{l}\text { SEA } 4 \\
2011\end{array}$ & $\begin{array}{l}\text { SEA } 5 \\
2012\end{array}$ & $\begin{array}{l}\text { SEA } 6 \\
2012\end{array}$ & $\begin{array}{l}\text { SEA } 7 \\
2013\end{array}$ & $\begin{array}{l}\text { SEA } 8 \\
2015\end{array}$ & $\begin{array}{l}\text { SEA 9 } \\
2015\end{array}$ & $\begin{array}{l}\text { SEA } 10 \\
2018\end{array}$ & $\begin{array}{l}\text { SEA } 11 \\
2016\end{array}$ & $\begin{array}{l}\text { SEA } 12 \\
2016\end{array}$ & $\begin{array}{l}\text { SEA } 13 \\
2016\end{array}$ & $\begin{array}{l}\text { SEA } 14 \\
2016\end{array}$ & Comments/ discussion \\
\hline$L 1$ & $\begin{array}{l}\text { Openness, transparency \& equity: } \\
\text { Stakeholder perception on SEA practice, } \\
\text { Successful public consultation }\end{array}$ & $\mathrm{N}$ & $?$ & $?$ & $\mathrm{P}^{* 4 L 1}$ & $?$ & $\mathrm{~N}^{* 6 \mathrm{~L} 1}$ & $\mathrm{P}$ & $?$ & $?$ & $?$ & $P$ & $\mathrm{~N} / \mathrm{A}$ & $\mathrm{N} / \mathrm{A}$ & ? & $\begin{array}{l}\text { Justified based on accessible information i.e. } \\
\text { regulators'/ relevant actors' websites }\end{array}$ \\
\hline$L 2$ & 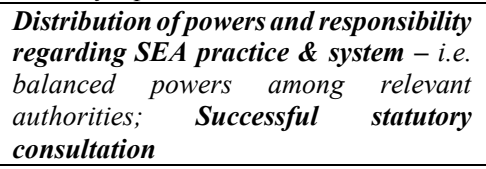 & $\mathrm{N}$ & ? & ? & $\mathrm{P}$ & $P$ & $?$ & $P$ & $\mathrm{~N}$ & $\mathrm{~N}$ & $\mathrm{~N}$ & $\mathrm{P}$ & $\mathrm{N} / \mathrm{A}$ & $\mathrm{N} / \mathrm{A}$ & $\mathrm{P}$ & $\begin{array}{l}\text { Analysed based on public participation techniques } \\
\text { applied in the SEA processes. }\end{array}$ \\
\hline$L 3$ & $\begin{array}{l}\text { Knowledge accuracy - the evidence base } \\
\text { applied in SEA process was reliable. }\end{array}$ & $\mathrm{P}$ & $P$ & Y & Y & Y & $?$ & Y & Y & Y & Y & Y & Y & $?$ & Y & $\begin{array}{l}\text { All cases were conducted by research scholars and } \\
\text { licensed consultants }\end{array}$ \\
\hline L4 & $\begin{array}{l}\text { Knowledge integration - all key findings } \\
\text { were utilised in } \begin{array}{r}\text { subsequent } \\
\text { stages/decisions, }\end{array} \text { Satisfactory/ }\end{array}$ & $\mathrm{N}$ & $\mathrm{N}$ & $\mathrm{N}$ & $P$ & $\mathrm{P}$ & $\mathrm{P}$ & $\mathrm{P}$ & $\mathrm{N} / ?$ & $\mathrm{~N} / ?$ & $\mathrm{~N} / ?$ & Y & $\mathrm{N} / ?$ & $\mathrm{~N} / ?$ & $\mathrm{P}$ & $\begin{array}{l}\text { No evidence presented explicitly that the SEA } \\
\text { findings were used in subsequent stages/ decisions. }\end{array}$ \\
\hline
\end{tabular}




\begin{tabular}{|c|c|c|c|c|c|c|c|c|c|c|c|c|c|c|c|c|}
\hline & $\begin{array}{l}\text { understandability/ comments in using } \\
\text { SEA in decision-making process }\end{array}$ & & & & & & & & & & & & & & & \\
\hline$L 5$ & $\begin{array}{l}\text { Knowledge diffusion - the full range of } \\
\text { evidence regarding the SEA practice was } \\
\text { able to be accessed }\end{array}$ & $\mathrm{N}$ & $\mathrm{N}$ & $\mathrm{N}$ & $\mathrm{N}$ & $\mathrm{N}$ & $\mathrm{N}$ & $\mathrm{N}$ & $\mathrm{N}$ & $\mathrm{N}$ & $\mathrm{N}$ & $\mathrm{Y}$ & $\mathrm{N}$ & $\mathrm{N}$ & $P$ & $\begin{array}{l}\text { Assessed based on accessibility of the SEA } \\
\text { findings i.e. websites, online database, and key } \\
\text { relevant authorities }\end{array}$ \\
\hline$L 6$ & $\begin{array}{l}\text { Knowledge spectrum - both formal and } \\
\text { informal knowledge was integrated in } \\
\text { the SEA process. }\end{array}$ & $\mathrm{N}$ & $\mathrm{N}$ & $P$ & $P$ & $\mathrm{~N}$ & $\mathrm{~N}$ & $\mathrm{~N}$ & $\mathrm{~N}$ & $\mathrm{~N}$ & $\mathrm{~N}$ & $\mathrm{P}$ & $\mathrm{N}$ & $\mathrm{N}$ & $\mathrm{N}$ & $\begin{array}{l}\text { Analysed based on public participation techniques } \\
\text { applied, and the ranges of stakeholders took part in } \\
\text { the SEA processes. }\end{array}$ \\
\hline
\end{tabular}

\section{criterions}

\section{Additional notes regarding SEA cases}

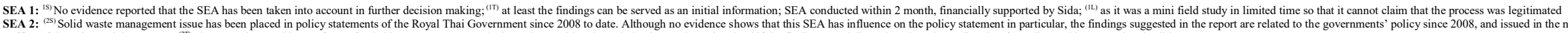

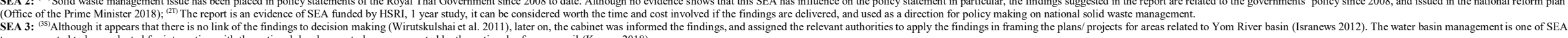
types suggested to be conducted for integrating with the national development plan, as suggested by the national reform council (Kumpa 2018

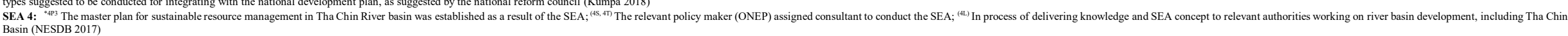

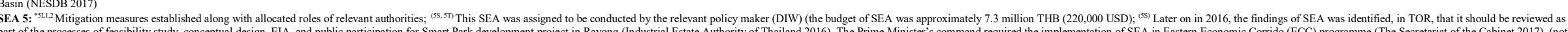

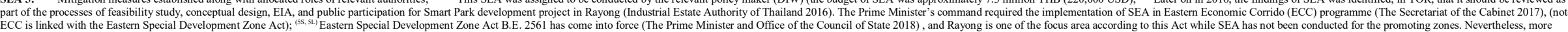

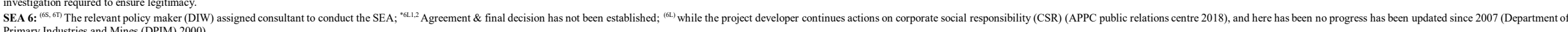
SEA 7: ${ }^{(5)}$ National Environment Board (NEB) resolution granted while additional comments by NEB proposed (Minister of Natural Resources and Environment 2016); ${ }^{(\pi)}$ The findings of SEA is an evidence, invested by the project developer, which can be applied for further development planning

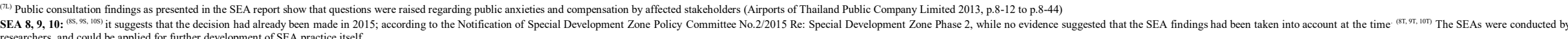

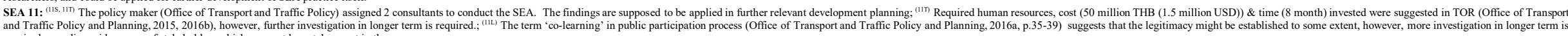
SEA 12: (125, 127, 121) Not able to evaluate as no evidence which links with decision-making is fund accessible

SEA 13: Not able to evaluate because the information presented in the paper was too brief. No evidence which links with decision-making is found/ accessible.

presented in the paper, and no evidence which links with decision-making is found/ accessible.

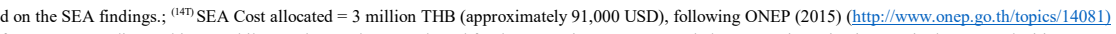

Eastern Special Development Zone Act BE. 2561 has come into force (The Prime Minister and Office of the Council of State 2018). Rayong is one of the focus area according to this Act while SEA has not ben conducted for the promoting zones. Nevertheless, More investigation required to ensure legitimacy. 


\subsection{Procedural effectiveness}

In regard to the question "Have appropriate processes been followed that reflect institutional and professional standards and procedures?", the findings suggest that all SEA practitioners attempted to adopt relevant concepts in conducting SEA, i.e. EIA serving as the SEA guideline for those SEAs conducted prior to 2009, and following the 2009 SEA guide subsequently. However, whilst the relevant policy framework and procedures for an SEA process (P1) are available in the Thai context, the SEA guideline, although available, has not been fully mandated (Prince of Songkla University 2018, World Bank 2006). This makes the time enforcement (P8) criterion meaningless in this circumstance. Based on those SEAs provided by policy making authorities or the regulators (SEA4, SEA5, SEA7, SEA11, SEA14), although the SEA guideline was available, the SEAs only partially achieved other procedural criteria, i.e. institutional characteristics (P2), integrating SEA in planning process of national development policy framework (P3), identification of financial fund for SEA practice (P4), involvement of stakeholders in the SEA process (P5), capacity of SEA to present clear understanding to decision making (P6), delivering SEA findings to participating stakeholders (P7). Sandang and Poboon (2018) stated that the SEA guideline should be revised to better reflect the Thai context (linked with $\boldsymbol{P 1}$ ); there is a lack of both key institutions directly in charge of SEA application and available data for SEA practice (linked with $\boldsymbol{P 2}$ ), and public participation in the SEA process (linked with $\boldsymbol{P 5}$ ) should be promoted and strengthened across all relevant actors.

While the findings suggest that lack of mandatory SEA is a weakness for Thailand at present, the key strengths of procedural effectiveness in Thai SEAs found here (justified based on the frequency of ' $\mathrm{Y}$ ' that the SEAs achieved for each sub-criterion) are the identification of financial fund supporting $S E A$ practice (P4), and the 
involvement of stakeholders in SEA process (P5). Initially, the Health System Research Institute funded some limited SEA research (SEA2, SEA3), but later the authorities in charge of governmental policy/programme/plan development, i.e. ONEP, DIW, and OTP allocated some funds to contract consultants for some SEAs (SEA4, SEA5, SEA6, SEA7, SEA11, SEA14). However, SEA costs, e.g., for public participation in the SEA process, are high and considered by others as a weakness (Sandang and Poboon 2018, Settasirote 2007). Currently, as indicated in section 1, financial support for the development of additional SEA case studies and for system development, i.e. 250 million THB for 3 years' operation, has been allocated, which suggests that effectiveness may increase in the future.

\subsection{Substantive effectiveness}

Overall assessment of the question: To what extent does the assessment lead to changes in process, actions, learning or outcomes? suggests that achieving substantive effectiveness is challenging (see Figure 1). Nevertheless, as they are connected with target areas of development driven by the national reform steering assembly, it appears that the SEAs for cases SEA4, SEA5, SEA7, SEA11, and SEA14 partially achieve some substantive criteria $(\boldsymbol{S} 2-\boldsymbol{S} 7)$.

While there is a policy framework concerning SEA (presented as P1), there has been no regulatory framework for implementing SEA in decision-making (S1) as SEA has never been mandatory in Thailand (World Bank 2006, Sandang and Poboon 2018, Yusook 2018, Prince of Songkla University 2018).

In terms of incorporation of proposed changes i.e. SEA was taken into account in the final version of the policy/plan (S2), it appeared that five SEAs (SEA2, SEA5, SEA7, SEA11, SEA14) partially meet, or fully meet this criterion. For example, the SEAs related to Rayong development and ecosystem services management (SEA5 \& SEA14) 
may partially, and implicitly, achieve the incorporation of proposed changes (see remarks in Table 3 for both cases). This is because the SEA findings were identified in Terms of Reference for the feasibility study, conceptual design, EIA, and public participation exercise for the Smart Park development project in Rayong (Industrial Estate Authority of Thailand 2016). In addition, to ensure that the findings of future SEAs are implemented practically, the Prime Minister's command no.384/2560 (The Secretariat of the Cabinet 2017) stated that the Ministry of Natural Resources and Environment and NESDC are the key authorities to provide a platform for applying SEA in key development areas, e.g., water basin management (linked with SEA2), transportation, coastal erosion prevention (linked with SEA11), airport development plan (linked with SEA7), and Eastern Economic Corridor (ECC) development programme (linked with SEA5 \& SEA14). This suggests the key driver roles for implementing SEA in development initiated at a strategic level.

It was not simple to justify informed decision-making (S3) based on documentary analysis alone. This is because access to the full reports and other official SEA-related documents is limited. As such, only five SEAs (SEA4, SEA5, SEA7, SEA11, SEA14) partially meet this criterion. The SEAs of the Special Economic Zone development strategy in Chiang Rai and Kanchanaburi (SEA8, SEA9, SEA10) were judged to fail against this criterion because there was no evidence to suggest that the SEA findings had been taken into account.

The SEA cases (SEA4, SEA5, SEA6, SEA7, SEA11, SEA14) tend to partially meet the rest of the criteria in the substantive category i.e. Close collaborations (S4), parallel development (S5), early start (S6), and Institutional and other benefits (S7) (see Table 3). 
The findings here agree with Settasirote (2007) who found that the influence of political context and the lack of clarity over the authority with responsibility for driving the implementation of SEA could affect the levels on SEA effectiveness.

\subsection{Transactive effectiveness}

While the transactive effectiveness concept may sound straightforward regarding resources invested, "its evaluation remains very challenging in practice" (MorrisonSaunders 2018, p.146). Nevertheless, the overall finding for the question: To what extent, is the outcome of conducting the assessment considered to be worth the time and cost involved? was that the SEAs were partially worth the time and cost involved. As the SEA cases were conducted by researchers, consultancies, or higher education institutions, they partially achieved transactive effectiveness criteria in terms of skills (T3) invested. This was apparent from the lists of staff taking part in SEA practice, and available TORs used to recruit consultants to conduct the SEA study. The range of time (T1) taken to conduct SEA is approximately 8-12 months, while the cost (T2) of conducting an SEA can vary from 3 - 50 million THB (0.1 - 1.6 million US dollars); according to data available on the websites of policy makers (ONEP, OTP) and the regulator (DIW) (see Table 3 for relevant cases).

In terms of specification of roles (T4), seven SEAs (SEA2, SEA3, SEA4, SEA5, SEA7, SEA11, SEA14) achieved, or partially achieved, this criterion based on the fact that the cases were conducted by researchers and/or professionals in the impact assessment field; the roles of the team members were identified as part of the SEA reports; and meetings were arranged to report the progress of SEA to the assigned expert panel for the research case (i.e. SEA3). Meanwhile, a lack of data meant that this criterion could not be appraised for other cases (SEA1, SEA6, SEA8, SEA9, SEA10, SEA12, SEA13): conducting interviews with the SEA team of the cases would lead to more 
clarification on how they allocated their roles. It has been suggested that the availability of human resources (T5) in SEA practice is inadequate (Sandang and Poboon 2018, Settasirote 2007). In the sample, eight SEAs were conducted by researchers and consultants, and so it can it can be argued that, overall, this criterion is partially met.

\subsection{Legitimacy}

The overall results to address the question: Was the assessment process perceived to be legitimate by a wide range of stakeholders? suggest that legitimacy for SEA practice is challenging to achieve. The findings show that public accessibility to the full range of SEA practice and findings could improve perceptions of legitimacy. This is directly related to criterion L5 Knowledge diffusion - Can the full range of evidence regarding the SEA practice be accessed? The selection of case studies for evaluation, in the first instance, was already determined by this criterion. While this seems to score well for the 14 SEA case studies examined in this research, a further 13 cases were not accessible online. This reflects a lack of legitimacy on knowledge diffusion for the SEA system as a whole. Specifically, 12 of the examined cases did not meet this criterion because of the lack of the full range of evidence expected.

The results also show that 12 SEAs are likely to fully or partially meet the knowledge accuracy (L3) criterion. This is because the SEAs were conducted by qualified research scholars and professionals. Apart from this criterion, the overall picture reveals that the SEA system is unlikely to achieve legitimacy in terms of openness, transparency \& equity (L1), distribution of powers and responsibility regarding SEA practice \& system (L2), knowledge integration (L4), knowledge diffusion (L5), and knowledge spectrum (L6). Only the Southern Coastal Area Development SEA (SEA11) partially achieved legitimacy. Openness of information related to impact assessment processes to the public is still considered limited, while 
'conflicts of interest in the roles of key stakeholders' is one of the key challenges in Thailand (Phromlah 2018, p.145).

That said, our evaluation was based solely on documentary analysis; it is entirely possible that other perspectives would be realised had stakeholders involved in each of the case studies been consulted to solicit their perceptions of legitimacy. More investigation over a longer period of time is required to include the wider range of stakeholders which may not have taken part in the process yet.

\section{Conclusion:}

This paper has evaluated the effectiveness of the SEA system in the Thai context. Although the SEAs were discretionary, most are related to focused area development through which Thailand is dealing with unresolved issues related to river basin management, special economic development zones, potash mining, and development in Rayong and the east coastal zone.

Based on the most up-to-date literature conceptualising effectiveness, disaggregated criteria have been synthesised and, where needed, developed, in order to create an effectiveness evaluation framework. This framework should be transferable to other contexts and is itself a significant outcome of this research.

Applying the evaluation framework to the Thai SEA context suggests that procedural effectiveness can be strengthened by providing a mandate for SEA, as well as allocating mandatory roles for relevant authorities. Strengthening the public participation process by designing creative approaches which fit with the context for all levels of stakeholders would facilitate good practice and learning. We consider this, and better knowledge diffusion, as being fundamental to achieving legitimacy. It is also emphasised that strengthening transactive effectiveness in terms of human resources, availability and 
skills would help in driving meaningful and effective practice for SEA. This would be an important accompaniment to the financial support that has been promised for SEAs of focused development areas in the country. SEA is evolving in Thailand, so this study is the starting point for understanding the SEA effectiveness journey in this country. Although the documentary analysis has some limitations as a data source for the effectiveness evaluation framework, the framework can reflect trends in overall performance of SEA practice, identifying overlooked issues and gaps. It also can help reflect the shape of desirable SEA practice and implementation. 


\section{References}

Airports of Thailand Public Company Limited. 2013. Strategic Environmental Assessment (SEA) in adjacent zones of Suvarnabhumi Airport (in Thai). Bangkok, Thailand.

Amornpitakpun R. 2018. Strategic Environmental Assessment (in Thai) - invited lecture at Suranaree U. of Technology. In: Bangkok: ONEP.

APPC public relations centre. 2018.Udon Potash mining project [Online] Available from https://udonpotash-news.blogspot.com/

Baker DC, McLelland JN. 2003. Evaluating the effectiveness of British Columbia's environmental assessment process for first nations'participation in mining development Environmental Impact Assessment Review.23:581-603.

Bond A, Morrison-Saunders A, Howitt R. 2013. Chapter 8: Framework for comparing and evaluating sustainability assessment practice. In: Sustainability Assessment: Pluralism, Practice and Progress London: Routledge (Taylor and Francis Group) pages 117-131.p. 117-131.

Bond A, Morrison-Saunders A, Retief F. 2016. A game theory perspective on environmental assessment: what games are played and what does this tell us about decision making rationality and Legitimacy? Environmental Impact Assessment Review.57:187-194.

Bond A, Pope J, Retief F, Morrison-Saunders A. 2018. On legitimacy in impact assessment: An epistemologically-based conceptualisation. Environmental Impact Assessment Review.69:16-23.

Bowen GA. 2009. Documentary analysis as a qualitative research method. Qualitative Research Journal.9:27-40.

Chanchitpricha C, Bond A. 2013. Conceptualising the effectiveness of impact assessment processes. Environmental Impact Assessment Review.43:65-72.

Chanchitpricha C, Bond A. 2018. Investigating the effectiveness of mandatory integration of health impact assessment within environmental impact assessment (EIA): a case study of Thailand. Impact Assessment and Project Appraisal.36:1631.

Department of Industrial Works. 2012. Strategic Environmental Assessment (SEA) of Mueang Rayong district and the adjacent zones (in Thai). Bangkok, Thailand.

Department of Primary Industries and Mines (DPIM). 2000. Progress of Potash mining project (in Thai) [Online]. Available:

http://www1.dpim.go.th/nal2/natitle.php?tid=000001100156849\&xnews=1 [Accessed October 2018].

Department of Primary Industries and Mines. 2012. Strategic Environmental Assessment (SEA) for Potash Mining Development [Online] Bangkok. Available: http://www.itdiproject.com/potash/ [Accessed October 2018].

Environmental Protection Department. 2007. Review of the International Water Resources management Policies and Actions and the Latest Practice in their Environmental Evaluation and Strategic Environmental Assessment: Final Report.

Fundingsland Tetlow M, Hanusch M. 2012. Strategic environmental assessment: the state of the art. Impact Assessment and Project Appraisal.30:15-24.

Haesakul S, Ratchawong P, Liamsungnoen S, Kueasirikul C, Prapawadee O, Khankampoke T, Raknatee S-a, Apichattrai S, Wilaijit P, Promporchuenboon C, et al. 2007. Developing public policy process and alternatives by using Strategic 
Environmental Assessment : a case study of Solid Waste Management in Thailand (in Thai). Nontaburi, Thailand.

Industrial Estate Authority of Thailand. 2016. Terms of Reference: Smart Park.

Available from

http://www.ieat.go.th/supply/search?keyword=เขตเศรษฐกิจพิเศษ\&industrial_esta te_code=\&start_dt=\&end_dt=[Accessed 2018].

International Association for Impact Assessment (IAIA). 2002. Strategic environmental assessment performance criteria. Journal]. Available from:

http://www.iaia.org/uploads/pdf/sp1.pdf

Isranews. 2012. Four options: the results of Yom River basin SEA (in Thai) Isara news Sect. Section|:Start Page| (col. Column)|.

Joomlee P, Wirojanagud W. 2016. Assessment of Potential Industrial Estate Site using Strategic Environmental Assessment Approach: Case Study of Khon Khaen Province (in Thai). The National and International Graduate Research Conference 2016

Kumpa L. 2018. SEA driving force in Thailand (in Thai). In: The seminar on SEA and water resource management in Thailand, 26 June 2018, The Berkeley, Hotel, Bangkok [Online] Available: http://www.onep.go.th/eia/กฎหมายที่เกี่ยวข้อง/sea/ [Accessed 2018].

Lee N, Colley R, Bonde J, Simpson J. 1999. Reviewing the Quality of Environmental Statement and Environmental Appraisals. Manchester.

Lindberg T, Nyllander A. 2001. Strategic Environmental Assessment on shrimp farms in the southest of Thailand (Mini field studies no. 176).

Merad M, Trump BD. 2018. The legitimacy principle within French risk public policy: A reflective contribution to policy analytics Science of the Total Environment.645:1309-1322.

Minister of Natural Resources and Environment. 2016. National Environment Board Resolution no.4/2558 and no.5/2558. In.

Morrison-Saunders A. 2018. Advanced introduction to environmental impact assessment Cheltenham, UK: Edward Elga Publishing Limited.

Namee J, Rooachanakanan R. Strategic Environmental Assessment for Tourism: A Case study of Tourism Group Area of Phu Kradueng, Nong Hin and Phu Luang, Loei Province, Thailand (in Thai). Proceedings of the FORCONS 2016; 2016.

National Reform Steering Assembly. 2017. The Report of The National Reform Steering Assemble on Public Health and Environment: Reform of Environmental Impact Assessment System in Thailand. Bangkok.

NESDB supports SEA concept \& guideline (in Thai) Bangkok. Available from http://www.nesdb.go.th/mobile_detail.php?cid=7\&nid=6777

Office of the Prime Minister. 2018. Prime Minister Office Notification Re: the announcement of the national reform plan (in Thai). In: No135 Section 24 a 6 April BE 2561, Bangkok.

Office of Transport and Traffic Policy and Planning. 2016. Executive Summary Report. The Study of Strategic Environmental Assessment (SEA) for the Development of the Southern Coastal Areas.

ONEP. 2009. Strategic Enironmental Assessment: SEA (in Thai): Office of Natural Resources and Environment Policy and Planning (ONEP).

ONEP. 2011. Strategic Environmental Assessment of Tha Chin River Basin for sustainable development (in Thai). Bangkok, Thailand.

ONEP. 2016. Strategic Environmental Assessment for ecosystem services in the Gulf of Thailand (the east coastal zone) (in Thai). Bangkok. 
Phromlah W. 2018. Public participation: how can we make it work for the environmental impact assessment system in Thailand? Asia Pacific Journal of Environmental Law.21:126-146.

Prince of Songkla University. 2018. Sustainable development and environmental impact assessment. Faculty of Law. Available from http://www.bangkokbiznews.com/blog/detail/644609. In: Bangkokbiznews.

Putta J, Poboon C. 2015. Strategic environmental assessment (SEA) of Kanchanaburi special economic zone (SEZ) development strategy (in Thai). Journal of Thai Interdisciplinary Research.10:8-15.

Sadler B. 1996. International study of the effectiveness of environmental assessment, Final report. Ottawa.

Sandang C, Poboon C. 2018. Strategic Environmental Assessment in Thailand (in Thai). Journal of Community Development Research (Humanities and Social Sciences).11:90-100.

Settasirote B. 2007. Experience and lessons learned from applying SEA for Yom Basin management. In: Management of Yom River Basin by using SEA (in Thai) Nonthaburi, Thailand: proposed to Thai Health Promotion Foundation (THPF), National Health Foundation (NHF), Health Systems Research Institute (HSRI).

Settasirote B, Sriburi T, Siwaraksa P, Yaowalert H, Ratchawong P, Haesakul S, Sampao P. 2007. Management of Yom River Basin by using SEA (in Thai). Nonthaburi, Thailand.

Tengsakul D, Poboon C. 2015. Strategi Environmental Assessment (SEA) of Special Economic Zone (SEZ) Development Strategy, Chiang Saen District, Chiang Rai Province. Journal of Community Development Research (Humanities and Social Sciences).8:125-138.

The Prime Minister, Office of the Council of State. 2018. Eastern Special Development Zone Act B.E. 2561 (in Thai) In: The Royal Thai Government Gazette, No 135, Section 34a Thailand: Cabinet and Royal Government Gazette Publishing Office.

The Secretariat of the Cabinet. 2017. The command as appointed by the Prime Minister as of 01/08/2017 [Online] Available: http://www.cabinet.soc.go.th/soc/. [Accessed October 2018].

The Secretariat of the House of Representatives. 2015. The National Reform Council: Reform agenda 25 Resource management system: EIA system reform. In: Bangkok: The Secretariat of the House of Representatives,.

Theophilou V, Bond A, Cashmore M. 2010. Application of SEA Directive to EU structural funds: Perspectives on effectiveness. Environmental Impact Assessment Review.30:136-144.

Uttano C, Poboon C. 2018. Strategic Environmental Assessment: A Case Study of the Special Economic Zone Chiang Khong District, Chiang Rai Province (in Thai).

Research and Development Journal Suan Sunandha Rajabhat University.10:142-158.

Victor D, Agamuthu P. 2014. Policy trends of strategic environmental assessment in Asia. Environmental Sciences \& Policy.41:63-76.

Wang H, Bai H, Liu J, Xu H. 2012. Measurement indicators and evaluation approach for assessing Strategic Environmental Assessment effectiveness. Ecology Indicators.23:413-420.

Wirutskulshai U, Sajor E, Coowanitwong N. 2011. Importance of context in adoption and progress in application of strategic environmental assessment: Experience of Thailand. Environmental Impact Assessment Review.31:352-359.

Wood C. 2003. Environmental impact assessment: a comparative review Edinburgh: Prentice Hall. 
World Bank. 2006. Environmental Impact Assessment Regulations and Strategic Environmental Assessment Requirements [Online].Environment and Social Development Department (East Asia and Pacific Region). Washington, D.C. Available:

http://documents.worldbank.org/curated/en/949001468167952773/pdf/408730PA PER0EI1 onal1 review01 PUBLIC1.pdf [Accessed 2015].

Yusook S. 2018. Part 1: The roles of Strategic Environmental Assessment (SEA) (in Thai). In: The seminar on SEA and water resource management in Thailand, 26 June 2018, The Berkeley Hotel, Bangkok [Online] Available: http://www.onep.go.th/eia/กฎหมายที่เกี่ยวข้อง/sea/ [Accessed 2018]. 